\title{
The Economics of Rotating Savings and Credit Associations (ROSCAs) and Poverty in Indonesia
}

\author{
Bayu Kharisma $^{1^{*}}$, Sutyastie S.Remi ${ }^{2}$, Ferry Hadiyanto ${ }^{3}$, Andhika D.Saputra ${ }^{4}$ \\ ${ }_{1,2,3,4}$ Department of Economics, Universitas Padjadjaran, Indonesia

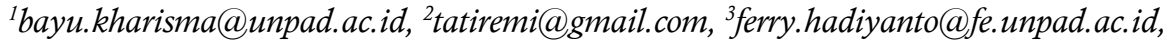 \\ ${ }^{4}$ andhika15003@mail.unpad.ac.id, *corresponding author
}

\begin{abstract}
Arisan or Rotating Savings and Credit Associations (ROSCAs) constitute one of the most commonly found informal financial institutions in the developing world. This study aims to analyze the effect of Rotating Savings And Credit Associations (ROSCAs) on poverty in Indonesia using panel data sourced from the fourth and fifth wave of the Family Life Survey (IFLS). This study used a conditional logit or fixed effect logit to see the effect of Rotating Savings and Credit Associations (ROSCAs) participation and control variables, which include individual, household, and community characteristics on poverty variables that are binary or categorized. The results showed that Rotating Savings and Credit Associations (ROSCAs) participation can reduce poverty. Meanwhile, this study shows that women who participate in Rotating Savings and Credit Associations (ROSCAs) can reduce poverty significantly.
\end{abstract}

Keywords: poverty, ROSCAs, IFLS, conditional logit

\section{Ekonomi Arisan dan Kemiskinan di Indonesia}

\begin{abstract}
Abstrak
Arisan atau Rotating Savings and Credit Associations (ROSCAs) merupakan salah satu lembaga keuangan informal paling umum yang terdapat di negara berkembang. Penelitian ini bertujuan untuk melihat pengaruh arisan (ROSCAs) terhadap kemiskinan di Indonesia dengan menggunakan data panel yang bersumber dari Indonesia Family Life Survey (IFLS) gelombang keempat dan kelima. Metodologi yang digunakan dalam penelitian ini adalah Conditional Logit atau Fixed Effect Logit untuk melihat pengaruh variabel partisipasi arisan dan variabel kontrol yang meliputi karakteristik individu, rumah tangga, dan komunitas terhadap variabel kemiskinan yang bersifat biner atau kategori. Hasil penelitian ini menunjukkan bahwa partisipasi arisan dapat mengurangi kemiskinan. Selain itu, penelitian ini menunjukkan bahwa perempuan yang berpartisipasi dalam arisan dapat mengurangi kemiskinan secara signifikan.
\end{abstract}

Kata kunci: Kemiskinan, arisan, IFLS, conditional logit

\section{INTRODUCTION}

Poverty is a global problem which both developing and developed countries face; poverty transcends geographical limitations. In general, poverty is a condition in which a person cannot or have difficulty in meeting their daily basic needs and their family's basic needs. Poverty can also be interpreted as a person's per capita income that is below the minimum income level or the poverty line set by the government.

Poverty is the first goal of the Sustainable Development Goals (SDGs) program designed by the United Nations (UN). In the SDGs program, the UN states that $10 \%$ of the total world population, or 736 million people, are in extreme poverty lines, and around 1.3 billion people are in multidimensional poverty (UNDP, 2006; World Bank, 2018). Multidimensional poverty not only measures poverty in terms of per capita expenditure 
(monetary dimension) but also from basic food and basic non-food needs, such as clothing, house ownership, sanitation, access to education, and access to health.

Poverty is a global threat, especially for developing countries like Indonesia. Indonesia's dispersed 34 provinces spread over thousands of islands has resulted in increasing poverty problems, paving the way for uneven development, unequal distribution, and even price inequality of standard necessities in some remote areas (World Bank, 2006a). In a report released by the World Bank (2006b), there are five factors of poverty, namely; education, type of work, gender, access to basic health services and infrastructure, and geographical location.

A report titled "Financing the Sustainable Development Goals in ASEAN: Strengthening integrated national Financing frameworks to deliver 2030 Agenda", published by UNDP (2017) states that as many as 132 million people in Southeast Asia managed to escape extreme poverty, or $12 \%$ of the world's total poor population, with the most prominent contributors being Indonesia and Vietnam amounting to $90 \%$. At present, there are an estimated 36 million people in the Southeast Asian region still living below the international poverty line set by the World Bank. The majority is in Indonesia and the Philippines. This staggering number should be immediately addressed by Indonesia, as Indonesia has the largest population in Southeast Asia with many potential that can be developed to overcome poverty.

Table 1. Number of Poor Population and Percentage of Poor Population, 2007 - 2014

\begin{tabular}{ccc}
\hline Year & $\begin{array}{c}\text { Number of poor population } \\
\text { (Million People) }\end{array}$ & $\begin{array}{c}\text { Percentage of Poor Population } \\
(\%)\end{array}$ \\
\hline 2007 & 37,17 & 16,58 \\
2008 & 34,96 & 15,42 \\
2009 & 32,53 & 14,15 \\
2010 & 31,02 & 13,33 \\
2011 & 29,89 & 12,36 \\
2012 & 28,59 & 11,66 \\
2013 & 28,55 & 11,47 \\
2014 & 27,73 & 10,96 \\
\hline
\end{tabular}

Source: Badan Pusat Statistik (2016)

Although Indonesia has succeeded in suppressing the poverty rate in recent decades, the number is still huge. The 2018 data from the Central Statistics Agency shows that throughout the research period (2007-2014), the number of people in poverty in Indonesia tended to decrease each year ( see Table 1). In 2007, 37.17 million people, or $16.58 \%$ of the total population of Indonesia, were in poverty. In 2014, it decreased to 27.73 million people or $10.96 \%$ of the total Indonesian population. Thus, in the past eight years, the poverty rate in Indonesia has decreased, albeit insignificant. Reducing the poverty rate should become the government's primary concern. To disrupt the cycle of poverty, we need not only the government's effort but also the people's firm determination. The magnitude of poverty can be measured through the poverty lines of each country or by comparing income disparity 
per capita between layers of society. Absolute poverty uses the poverty line as a benchmark, while relative poverty compares differences in income per capita between layers of society.

Indonesia is a developing country rich in tradition, especially at the group or community level. One tradition in the economy is rotating savings and credit associations (ROSCAs) or arisan. According to the Indonesian Dictionary online, arisan is an activity to collect money or goods of equal value by a group of people and then draw in a meeting regularly until all members receive the funds (Kementerian Pendidikan dan Kebudayaan Republik Indonesia, 2016).

According to Anggreani (2009), rotating savings and credit associations (ROSCAs) or arisan is a financial source from the informal sector that has three main functions, namely securities or insurance, financial, and social. The function of securities or insurance and finance in question is arisan as a means to borrow money or save without interest or other fees that impose. The social function of arisan is seen from the context of the social gathering held in the community, family, and colleagues. Varadharajan (2004) defines rotating savings and credit associations (ROSCAs) or arisan as a group of people who hold regular meetings (either weekly or monthly) and collect a predetermined amount of money, at the end of the meeting determined who is entitled to get the amount of money that has been collected by drawing or by deliberation.

Rotating savings and credit associations (ROSCAs) is a forum for people, especially in rural areas, who are economically unable to obtain access to savings and obtain loans from formal or semi-formal financial institutions. These people prefer rotating savings and credit associations (ROSCAs) as they do not have to pay interest and other fees charged by formal and semi-formal financial institutions. From the economic side, rotating savings and credit associations (ROSCAs) functions as a means to save and borrow and beneficial for the poor to overcome urgent financial problems in the household. Someone who gets the draw will get a sudden injection of funds that can be used for their needs, either to support their family or to add to their assets (Yusuf, Ijaiya, \& Ijaiya, 2009). Adding these assets is useful for individuals or households to slowly improve their standard of living and will help them get out of the poverty line (Anggreani, 2009). From the social side, it serves as a means to socialize. When socializing, the person obtains additional information and connections related to job vacancies and business opportunities that can improve their living conditions. In addition, fellow members of rotating savings and credit associations (ROSCAs) can help each other if another experiences difficulties (Anderson \& Baland, 2002). Thus, hypothesis of this research that rotating savings and credit associations (ROSCAs) has a negative effect on poverty.

Past studies have analyzed the relationship between rotating savings and credit associations (ROSCAs) and poverty alleviation. The results are shown by participation in rotating savings and credit associations (ROSCAs) can use money for household needs (food, health, education, assets, and business activities), household size, education level, and other variables that can reduce poverty at the household level. Acquah \& Dahal (2018) explained that rotating savings and credit associations (ROSCAs) helped individuals and families to overcome financial problems during the 1998 Indonesian economic crisis. 
Kimuyu (1999) explained that rural East Africa uses the money from ROSCAs for food $(27 \%)$, tuition fees $(20 \%)$, durable goods or assets $(10.2 \%)$, and the remaining use it to promote small businesses, medical expenses, and repay debts. Yusuf, Ijaiya, \& Ijaiya (2009) showed that in Kwara State, Nigeria, rotating savings and credit associations (ROSCAs) can get households out of the poverty line as its money can be used for food, housing (rent), health, and business activities which positively affect poverty alleviation. Imai, Arun, \& Annim (2010) showed that Micro Finance Institution (MFI), which focuses on rotating savings and credit associations (ROSCAs) in India, has a vital role in reducing poverty. Anderson \& Baland (2002) showed that rotating savings and credit association (ROSCAs) helps increase household income and is used by the wife to help with children's school fees and household needs.

Based on the findings above, the objective of this study aims to determine the effect of rotating savings and credit association (ROSCAs) participation on poverty alleviation with cases in Indonesia that never been structured. This is significant as many poor people in Indonesia still faces challenges or do not have access to credit to help their financial problems. Rotating savings and credit association (ROSCAs) has bridged that lack of access and has become a tradition that can help save and borrow money and is a method of socializing among members.

\section{METHOD}

The data used in this study is the fourth and fifth wave of the Indonesia Family Life Survey (IFLS) data. IFLS is regularly collected by RAND Corporation in collaboration with the Central Statistics Agency. IFLS has published five survey waves to date. The fourth wave (IFLS 4) was carried out in 2007 with a sample of 44,103 individuals and 13,535 households in 15 provinces. The fifth wave (IFLS 5) was conducted from the end of 2014 to the beginning of 2015 with a sample of 50,148 individuals and 16,204 households.

Meanwhile, as data that can represent over $50 \%$ of the total population in Indonesia is limited, the researchers used panel data from the fourth wave IFLS (IFLS 4) and the fifth wave (IFLS 5), which represents $83 \%$ of the total population in Indonesia. In addition, this study used data from the Central Statistics Agency to obtain the value of Indonesia's poverty line in 2007 and 2014. After estimation, a likelihood ratio testing was done to determine whether all independent variables affect the dependent variable. This test is based on loglikelihood differences between the restricted and unrestricted models (Wooldridge, 2015). Next, the Goodness of fit test is done on the regression results to show how much the model in the study affects the estimation results compared to models outside the study.

This research uses descriptive and econometric methods by explaining the relationship of the independent variables on the processed dependent variable. The poverty variable is a variable with ordinal results. The model used is a conditional logit method as it can control unobserved heterogeneity, which is fixed over time with binary non-free variables. Furthermore, to determine the right model, a Hausman testing was carried out (Bergstrom et al., 2003). 
Jurnal Economia, 16(1), April 2020, 100-111

Table 2. Research Variables

\begin{tabular}{|c|c|}
\hline Variables & Explanation \\
\hline Poverty & $\begin{array}{l}\text { The poverty variable is obtained from the fourth wave and fifth wave IFLS per } \\
\text { capita expenditure (PCE) book. After that, the poverty variable is made by } \\
\text { selecting per capita expenditure based on data from the Central Statistics } \\
\text { Agency as follows: } \\
\text { - Category (0) is not poor, if income is above the poverty line (> 166,697 IDR } \\
\text { / month) in } 2007 \text { and (> 302,735 IDR / month) in } 2014 \text {. } \\
\text { - Category (1) is poor, if household income is below the poverty line (> 166,697 } \\
\text { IDR / month) in } 2007 \text { and (> 302,735 IDR / month) in } 2014 \text {. }\end{array}$ \\
\hline $\begin{array}{l}\text { The ROSCAs } \\
\text { participation }\end{array}$ & $\begin{array}{l}\text { The ROSCAs participation variable is obtained from the 3B book section PM } \\
\text { with the question in pm01: "Have you attended the social gathering in the last } \\
12 \text { months?". } \\
\text { With answers from respondents as follows: } \\
\text { •Category (0) does not follow a social gathering } \\
\text { - Category (1) follows the social gathering }\end{array}$ \\
\hline Gender & $\begin{array}{l}\text { This variable is obtained from the AR section } \mathrm{K} \text { book namely ar } 07 \text { which is } \\
\text { recoded to obtain gender. With answers from respondents as follows: } \\
\text { - Category ( } 0 \text { ) male } \\
\text { - Category (1) women }\end{array}$ \\
\hline Household Age & $\begin{array}{l}\text { This variable was obtained from book K section AR with a question in column } \\
\text { ar09: "How old are the household members now?" }\end{array}$ \\
\hline $\begin{array}{l}\text { Marital Status of } \\
\text { Household head }\end{array}$ & $\begin{array}{l}\text { This variable was obtained from the AR section K book namely ar13 which was } \\
\text { recoded to obtain marital status. With answers from respondents as follows: } \\
\text { - Category (0) is not yet married or separated } \\
\text { - Category (1) married or still married }\end{array}$ \\
\hline Year of Schooling & $\begin{array}{l}\text { This variable is obtained from the AR section } \mathrm{K} \text { books namely ar16, ar17 which } \\
\text { are recoded to get years of schooling }\end{array}$ \\
\hline Household Size & $\begin{array}{l}\text { This variable was obtained from the book section } \mathrm{K} \text { AR, namely ar01a which } \\
\text { was recoded to get the number of household members. }\end{array}$ \\
\hline Home ownership & $\begin{array}{l}\text { This variable was obtained from book } 3 \mathrm{~A} \text { of HR section namely hrltype and } \\
\text { hr01 which were recoded to get home ownership. }\end{array}$ \\
\hline $\begin{array}{l}\text { Water access to the } \\
\text { house }\end{array}$ & $\begin{array}{l}\text { This variable was obtained from book } 1 \mathrm{~A} \text { in the community level section } \mathrm{C} \\
\text { about access to water in the recoded house to get the following answers: } \\
\text { - Category (0) if you do not have access to water inside the house } \\
\text { - Category (1) if you have access to water inside the house }\end{array}$ \\
\hline Vehicle Ownership & $\begin{array}{l}\text { This variable was obtained from book } 3 \mathrm{~A} \text { of } \mathrm{HR} \text { section, namely hrltype and } \\
\text { hr01 which were recoded to get vehicle ownership. }\end{array}$ \\
\hline $\begin{array}{l}\text { Access to People's } \\
\text { Business Credit (KUR) }\end{array}$ & $\begin{array}{l}\text { This variable was obtained from book } 1 \mathrm{~A} \text { in the community level section } \mathrm{D} \\
\text { about loans made for agricultural and industrial purposes which were recoded } \\
\text { to obtain the following answers: } \\
\text { - Category (0) if they do not have access to people's business credit } \\
\text { - Category (1) if you have access to people's business credit }\end{array}$ \\
\hline Residence & $\begin{array}{l}\text { This variable was obtained from book K section SC with questions in column } \\
\text { sc } 05 \text {. With answers from respondents as follows: } \\
\text { - Category (0) if living in a rural area } \\
\text { - Category (1) if you live in an urban area }\end{array}$ \\
\hline
\end{tabular}

Source: RAND Corporation $(2007,2014)$ 
The model used to estimate the relationship between rotating savings and credit associations (ROSCAs) participation in poverty alleviation at the household level modifies the previous model carried out by Yusuf, Ijaiya \& Ijaiya (2009). The model will be explained in Equation 1 as follows.

$$
\operatorname{Pr}(\text { poverty })_{i t}=\alpha+\beta_{1} R O S C A_{i t}+\beta_{2} X_{i t}+U_{i t}
$$

where $\operatorname{Pr}$ (poverty) is the probability of being poor, ROSCAs is a rotating savings and credit associations (ROSCAs) participation, $X_{i t}$ are the variables that affect poverty, including, the sex of the head of the household $(\mathrm{HoH})$, age of the head of household, years of schooling of the head of household, marital status of the head of household, number of household members, home ownership, water access, vehicle ownership, KUR (community business credit), and residence. $\mathrm{U}_{\text {it }}$ is the error term.

\section{FINDING AND DISCUSSION}

The researchers used cross-section data sourced from the fourth (IFLS 4) and fifth (IFLS 5) Indonesia Family Life Survey. The researchers used several books with the individual, household, and community characteristics to obtain variables that fit the literature study discussed earlier. Furthermore, used the poverty line data sourced from the Central Statistics Agency. As per the IFLS 4 and IFLS 5 surveys, the 2007 poverty line was chosen with 166,697 IDR per capita per month and in 2014 with 302,735 IDR per capita per month. The number of samples obtained from the data processing is 5,518 observations. A full explanation of the variables used in the study is described in Table 3 below.

Table 3. Summary Statistics of Key Variables

\begin{tabular}{lcccc}
\hline \multicolumn{1}{c}{ Variable } & Obs. & Mean & Min & Max \\
\hline Poverty (poverty=1) & 5518 & 0.1057 & 0 & 1 \\
The ROSCAs participation (yes=1) & 5518 & 0.2819 & 0 & 1 \\
Gender Head of Household (male =1) & 5518 & 0.0433 & 0 & 1 \\
Household Head Age & 5518 & 45.0816 & 0 & 92 \\
Household Head Age Squared & 5518 & 2415.4790 & 0 & 8464 \\
Marriage Status (married =1) & 5518 & 0.8523 & 0 & 1 \\
Year of Schooling (years) & 5518 & 5.8142 & 0 & 16 \\
Household size & 5518 & 4.3378 & 2 & 15 \\
Home Ownership (yes =1) & 5518 & 0.6780 & 0 & 1 \\
Water access to the house (yes =1) & 5518 & 0.6754 & 0 & 1 \\
Vehicle Ownership (yes=1) & 5518 & 0.2138 & 0 & 1 \\
Access to People's Business Credit (KUR) (yes=1) & 5518 & 0.0159 & 0 & 1 \\
Residence (urban=1) & 5518 & 0.4126 & 0 & 1 \\
\hline Sumber: RAND Corporation (2007, 2014) & & & &
\end{tabular}

Sumber: RAND Corporation $(2007,2014)$

Table 3 indicates that the average individual classified as poor in the sample was 0.1057 , showing that the majority of the sample tended to be individuals living above the 
poverty line. The ROSCAs participation variable shows an average of 0.2819 which shows that there are more individuals who do not participate in rotating savings and credit associations (ROSCAs) than those who do. In the control variables, such as the sex of the head of household, it shows that the average is 0.0433 , which indicates that men dominate the samples more than women. The average age of head of household shows that the majority of head of household are 45 years old. The marital status of head of household shows that the average is 0.8523 , which indicates that most of the $\mathrm{HoH}$ are married. The years of schooling variable shows that the mean years of schooling of the head of household is six years. The average number of household members is four.

Other control variables, such as home ownership, shows an average of 0.6780 , which means that the sample is dominated by households that have private homes. Most of the households in the sample (0.6754) have access to water in their homes. Furthermore, the vehicle ownership variable shows an average of 0.2138 , which indicates that most of the samples do not own their vehicles. Variable access to people's business credit shows an average of 0.0159 , which indicates that most of the households do not have access to credit. The residence variable shows an average of 0.4126 , which means that most of the samples reside in rural areas.

The estimation results in Table 4 show that with a significance level of 99\%, households participating in rotating savings and credit associations (ROSCAs) have a probability to not be poor with a 0.3900 percentage point, higher than households that do not participate in ROSCAs, ceteris paribus. The estimation results in the second group show that with a significance level of $95 \%$, households participating in rotating savings and credit associations (ROSCAs) have a probability to not be poor with 0.2721 percentage points, higher than those households not participating, ceteris paribus. That is because individuals who participate can utilize money for daily living purposes, such as adding assets, future living needs, and even adding capital for business. The estimation results fit previous studies (Yusuf, Ijaiya \& Ijaiya, 2009; Imai, Arun \& Annim 2010; Besley, Coate \& Loury, 1994) which showed that rotating savings and credit associations (ROSCAs) could help save, increase income, assets and support productive purposes such as business. In addition, can help a group of people to allocate funds by forming an informal credit market.

The variable of the male head of household shows a negative relationship to poverty but is not significant. In This case in Indonesia still shows a gender injustice to work and income, which results in men obtaining a higher level of employment and income compared to women. The estimation results in line with the research by Imai, Arun \& Annim (2010), which explained that male heads of households have more income than women, and will use their money for business-related matters.

The estimation results in Table 4 show that each one year increase in the age of the head of household increases the probability of a household to not be poor by 0.0063 percentage points, ceteris paribus but is not significant. The age of the head of household shows a negative effect to poverty, as the older the head of household, the higher his productivity, up to a certain age, with more family members such as children growing up and being able to work, which will reduce the burden on the head of household. This 
supports the research of Yusuf, Ijaiya \& Ijaiya (2009) and Imai, Arun \& Annim (2010), which demonstrated that the older the head of household, the more productive he is up to a certain age. Furthermore, the Quadratic Result Variable of the age of the head of household shows that before the head of household reaches 26 years old, the household is poor, then after reaches 26 years old, the household will not be poor, ceteris paribus.

Table 4. Estimation Result

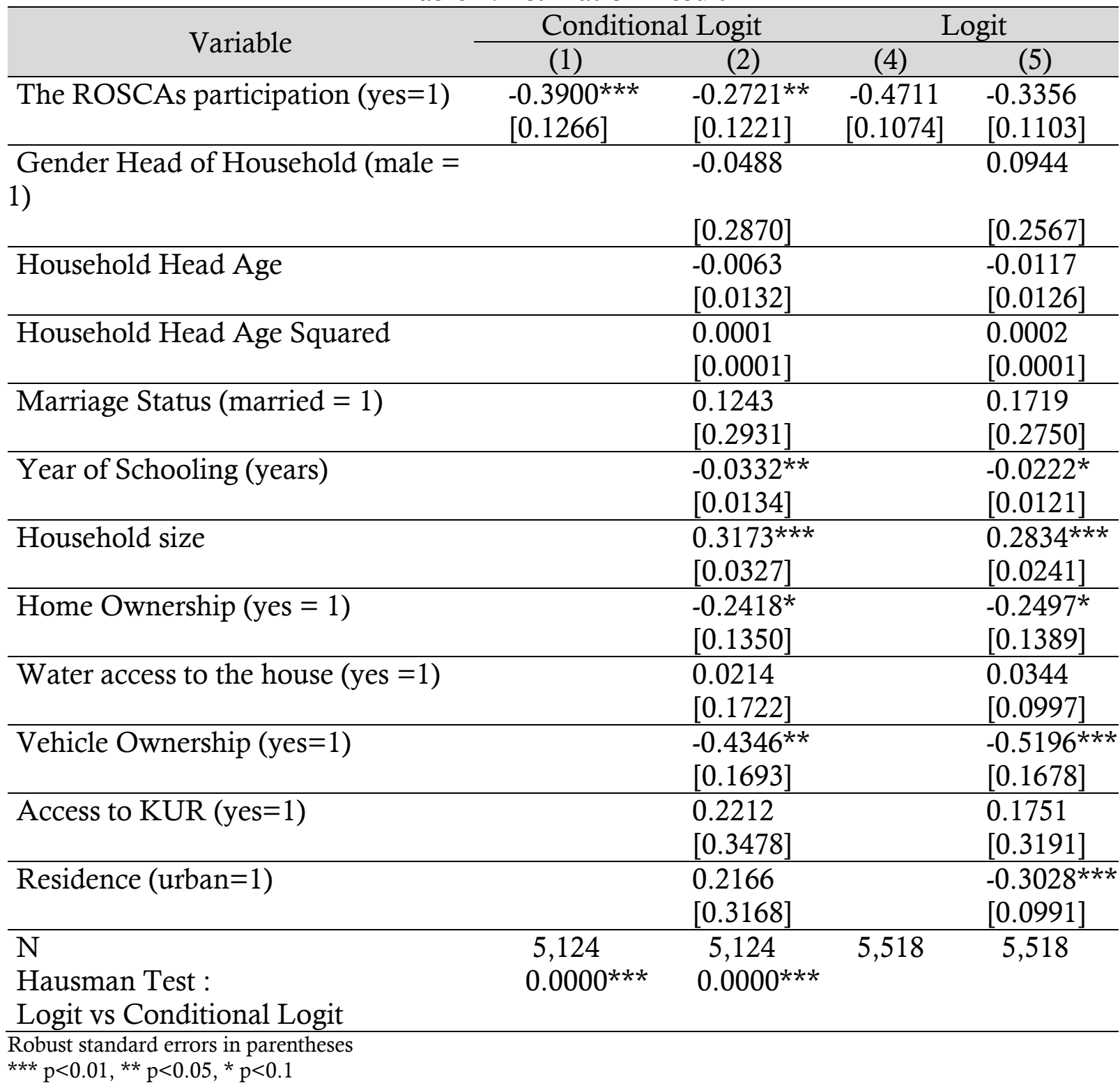

The married marital status of the head of household has a 0.1243 percentage point greater of being poor than unmarried head of household but is not significant, ceteris paribus. The marital status of the $\mathrm{HoH}$ has a positive effect with poverty, as married head of household will have an increasing living needs, especially with the addition of children. These facts support the research from Kapungwe (2004), which explained that married head of household bears more burdens and increasing basic living needs compared to unmarried head of household. 
The years of schooling have a negative effect on poverty as the higher the education level of the head of household with a significance level of $95 \%$, The greater the chance of obtaining a better job. This is consistent with previous research (Kimuyu, 1999; Yusuf, Ijaiya \& Ijaiya, 2009; Imai, Arun \& Annim, 2010), which showed that the higher the level of education of head of household, the higher the likelihood of finding higher-income jobs.With increasing education the head of the household has broader skills and opportunities at work, and therefore has the possibility to stay away from poverty. Furthermore, with increasing education, opportunities to gain access to information (employment information, markets, credit facilities, health, or personal development) will be greater, so that the benefits derived from this information are used to improve family welfare.

The number of household members shows a positive effect on poverty with a significance level of $99 \%$. The more the household members, the more financial burden it will create. This is consistent with previous research by Dagnelie \& Lemay- Boucher (2012), which showed that the more the household members, the more the burden will be borne by the head of household, especially if more family members are underage and elderly. This is in line with previous research that the greater the size of the household, the greater the poverty tends to be.

The home ownership variable has a negative effect on poverty with a significance level of $90 \%$. A household that owns their own home indicates that the household is above the poverty line or is economically well-off. This is as explained by Yusuf, Ijaiya \& Ijaiya (2009) and Imai, Arun \& Annim (2010), who stated that households or individuals who have assets in the form of houses are said to be economically capable.

Water access shows a positive effect on poverty but is not significant and the results are inversely proportional to the hypothesis; if a household does not have its water access, the household must spend money to buy clean water, as water is crucial for daily needs like drinking, cooking and sanitation purposes. These results are inversely proportional to the research of Ahmad (2003), which explained that water access in the home would facilitate daily household activities related to sanitation.

Vehicle ownership has a negative effect on poverty with a significance level of $95 \%$. Households that own their vehicles indicate that these households are above the poverty line or are economically well-off. This is as explained by previous research (Yusuf, Ijaiya \& Ijaiya, 2009; Imai, Arun \& Annim, 2010), which stated that households or individuals who have assets in the form of vehicles are considered economically well-off.

Access to people's business credit has a positive effect on poverty but is not significant. Business credit is intended for households with limited capital; thus, economically sufficient households will not get access to business credit. This supports the research of Johnston (2017), which explained that people's business credit is intended to increase capital for small and medium entrepreneurs with limited capital.

Residency shows that households in urban areas are positively affected towards poverty but is not significant. The cost of living such as clothing, food, and housing costs in urban areas is higher than in rural areas. Additionally, employment in urban areas requires 
a higher educational background, thus, individuals who lack expertise and high education will find it difficult to obtain decent jobs. This is in line with research conducted by Imai, Arun \& Annim (2010) and Varadharajan (2004) which explained that the cost of daily living such as clothing, food, and housing in urban areas is higher than in rural areas. Meanwhile, if it is related to work, it can be seen that households in urban areas are closer to work in the formal sector. Therefore, urban areas are lower in poverty compared to rural areas when related to the type of work.

Meanwhile, estimations were made to calculate how much rotating savings and credit associations (ROSCAs) influences poverty alleviation by dividing the sample by sex (see Table 5 for example). The estimation results in Table 5 show that with a significance level of $95 \%$, women who participated in rotating savings and credit associations (ROSCAs) have a probability to not be poor by 0.2886 percentage points greater than women who did not participate, ceteris paribus. Furthermore, the results of the marginal effect in the second group showed an insignificant level; men who participated in rotating savings and credit associations (ROSCAs) had a probability to not be poor with 0.3411 percentage points greater than men who did not participate, ceteris paribus. That is because women prefer to save their money through rotating savings and credit associations (ROSCAs) and will later be used for household purposes compared to men who invest more or for business purposes. The estimation results support the previous research conducted by Anderson \& Baland (2002), which shows that rotating savings and credit associations (ROSCAs) is used by a wife to help with children's school fees and household needs and. Furthermore, participation in a rotating savings and credit associations (ROSCAs) is a strategy a wife employs to protect her savings against claims by her husband for immediate consumption. More details can be seen in Table 5 below.

Table 5. Estimation Result By Sex

\begin{tabular}{llccc}
\hline \multirow{2}{*}{ Variable } & \multicolumn{2}{c}{ Conditional Logit } & \multicolumn{2}{c}{ Logit } \\
\cline { 2 - 5 } & Female & Male & Female & Male \\
\hline The ROSCAs & $-0.2886^{* *}$ & -0.3411 & -0.3802 & $-0.3402^{*}$ \\
participation (yes=1) & {$[0.1424]$} & {$[0.2244]$} & {$[0.1381]$} & {$[0.1904]$} \\
\hline $\mathrm{N}$ & 2,294 & 2,250 & 2,789 & 2,729 \\
Hausman Test : & $0.0000^{* * *}$ & $0.0000^{* * *}$ & & \\
Logit vs Conditional & & & & \\
Logit & & & & \\
\hline
\end{tabular}

Robust standard errors in parentheses

Additional Control: Household Head Age, Household Head Age Squared, Marriage Status (married = 1), Year of Schooling (year), Household size, Home Ownership (yes = 1), Water access to the house (yes =1), Vehicle Ownership (yes=1), Access to People's Business Credit (yes=1), Residence (urban=1)

$* * * \mathrm{p}<0.01,{ }^{* *} \mathrm{p}<0.05,{ }^{*} \mathrm{p}<0.1$

\section{CONCLUSION}

The findings of this study reinforce the findings of previous research, which showed that ROSCAs participation is positively effect with poverty alleviation. This research shows that women who participate in ROSCAs can significantly reduce poverty. Men who participate 
in ROSCAs can also reduce poverty but not significantly. Other factors such as the age of the head of the household, years of schooling of the head of the household, house ownership, access to water in the house, vehicle ownership, and households residing in rural areas also reduce poverty. However, there are several variables such as the married status of the head of household, the number of household members and access to people's business credit, which adds to poverty.

Recommendations to make ROSCAs have broad based impact on the people's wellbeing some of the problems that have hinderers members effective contribution to the growth and operation of the association should be addressed. Prominent among the problems are the problem of low-income earning of the members which has made saving mobilization difficult and the fear of default that is common among members. Thus, the government can augment the low-income earnings of members by making soft loans available to members through cooperative societies that the members belonged. The fear of default can be taking care of if members can institutionalized the concept of social capital that places emphasis on trust, information sharing, and reduction of opportunistic behavior and facilitation of collective decision-making.

\section{ACKNOWLEDGEMENT}

I would like to thank the anonymous referee for valuable comments and suggestions. We thank our colleagues from Department of Economics, Universitas Padjadjaran who provided insight and expertise that greatly assisted the research and we thank to "anonymous" reviewers for their so-called insights.

\section{REFERENCES}

Acquah, J. K., \& Dahal, R. (2018). ROSCAs as lenders of last resort after financial crises: lessons from indonesia. Journal of International Development, 30(7), 1223-1239. https://doi.org/10.1002/jid.3366

Ahmad, Q. K. (2003). Towards poverty alleviation: the water sector perspectives. International Journal of Water Resources Development, 19(2), 263-277. https://doi.org/10.1080/0790062032000089356

Anderson, S., \& Baland, J.-M. (2002). The economics of roscas and intrahousehold resource allocation. The Quarterly Journal of Economics, 117(3), 963-995. https://doi.org/10.1162/003355302760193931

Anggraeni, L. (2009). Factors influencing participation and credit constraints of a financial self-help group in a remote rural area: the case of ROSCA and ASCRA in Kemang village West Java. Journal of Applied Sciences, 9(11), 2067-2077.

Badan Pusat Statistik. (2008). Kemiskinan dan Ketimpangan. Publikasi BPS. Jakarta.

Badan Pusat Statistik. (2016). Kemiskinan dan Ketimpangan. Publikasi BPS. Jakarta.

Bergstrom, J.C et al. (2003). Use of chamberlain fixed effects approach to estimate willingness-to pay for little Tennessee river basin management alternatives. Selected 
Paper, Southern Agricultural Economics Association Meeting

Besley, T., Coate, S., \& Loury, G. (1994). Rotating savings and credit associations, credit markets and efficiency. The Review of Economic Studies, 61(4), 701-719. https://doi.org/10.2307/2297915

Dagnelie, O., \& Lemay- Boucher, P. (2012). Rosca participation in Benin: A commitment issue. Oxford Bulletin of Economics and Statistics, 74(2), 235-252. https://doi.org/10.1111/j.1468-0084.2011.00641.x

Imai, K. S., Arun, T., \& Annim, S. K. (2010). Microfinance and household poverty reduction: New evidence from India. World Development, 38(12), 1760-1774. https://doi.org/10.1016/j.worlddev.2010.04.006

Johnston, J. S. (2017). The Freedom to Fail: Market Access as the Path to Overcoming Poverty and Inequality. Harv. JL \& Pub. Pol'y, 40, 41.

Kapungwe, A. (2004). poverty in zambia: levels, patterns and trends. Development Southern Africa, 21(3), 483-507. https://doi.org/10.1080/0376835042000265450

Kementerian Pendidikan dan Kebudayaan Republik Indonesia. (2016). KBBI Daring: Arisan. Badan Pengembangan Bahasa dan Perbukuan. Jakarta.

Kimuyu, P. K. (1999). Rotating saving and credit associations in rural East Africa. World Development, 27(7), 1299-1308. https://doi.org/10.1016/S0305-750X(99)00049-2

UNDP. (2006). Goal 1: No poverty. Publikasi UNDP. New York.

UNDP. (2017). Financing the Sustainable Development Goals in ASEAN: Strengthening integrated national Financing frameworks to deliver 2030 Agenda. Publikasi UNDP. Thailand.

Varadharajan, S. (2004). Explaining Participation in Rotating Savings and Credit Associations (RoSCAs): Evidence from Indonesia, 1-58.

Wooldridge, J. M. (2015). Introductory econometrics: A modern approach. Nelson Education.

World Bank. (2003). World Development Report. Publikasi World Bank. Washington, DC.

World Bank. (2006a). Era Baru dalam Pengentasan Kemiskinan di Indonesia. The World Bank (p. XL).

World Bank. (2006b). Making the New Indonesia Work for the Poor. Publikasi World Bank. Washington, DC.

World Bank. (2018). Poverty and Shared Prosperity: Piecing Together the Poverty Puzzle. The World Bank Group (pp. 1-201). https://doi.org/10.1596/978-1-4648-1330-6

Yusuf, N., Ijaiya, G. T., \& Ijaiya, M. A. (2009). Informal financial institutions and poverty reduction in the informal sector of Offa town, Kwara state: A case study of rotating savings and credit associations (ROSCAs). Journal of Social Sciences, 20(1), 71-81. https://doi.org/10.1080/09718923.2009.11892724 